\title{
Exegesis - The Debate in TEXT
}

TEXT has been at the forefront of the debate on the exegesis and on the associated notions of the relationship of research to art practice. Below is a list of papers that have appeared in TEXT discussing aspects of this debate.

Aquilla, Pieter \& Pallotta-Chiarolli, Maria Truth or Fiction: Writing Narrative in Research Vol 1 No 1 April 1997

Bastow, Helen Milte Dialogues with a body called the research journal Vol 7 No 1 April 2003

Bourke, Nicole \& Brady, Tess The Novelist Enters the Library Vol 2 No 1 April 1998

Brady, Tess A Question of Genre: de-mystifying the exegesisVol 4 No 1 April 2000

Brophy, Kevin Some Things About Creative Writing: Three Stories Vol 2 No 1 April 1998

Comte, Annette Use of Feminist Literary Theory in Developing a Critical Language for Hypertext Vol 4 No 2 October 2000

Dawson, Paul Towards a New Poetics in Creative Writing Pedagogy Vol 7 No 1 April 2003

Dawson, Paul Writing Programs in Australian Universities: Creative Art or Literary Research? Vol 3 No 1 April 1999

Dibble, Brian \& van Loon, Julienne Writing Theory and/or Literary Theory Vol 4 No 1 April 2000

Freiman, Marcelle Crossing the Boundaries of the Discipline: A Post-colonial Approach to Teaching Creative Writing in the University Vol 5 No 2 October 2001

Harrison, Keith Narrative Theory / Creative Acts? Vol 7 No 1 April 2003

Keane, Jondi Fictive Certainty Underwrites Writing Vol 4 No 2 October 2000

Krauth, Nigel The Creative Writing Doctorate in Australia: An Initial Survey Vol 5 No 1 April 2001

Krauth, Nigel The Preface as Exegesis Vol 6 No 1 April 2002

Krauth, Nigel Where is Writitng Now?: Australian University Creative Writing Programs at the End of the Millennium Vol 4 No 1 April 2000

Kroll, Jeri Creative Writing as Research and the Dilemma of Accreditation: How do we prove the value of what we do? Vol 6 No 1 April 2002

Kroll, Jeri Honouring Students: What can a successful creative writing honours program offer? Vol 4 No 2 October 2000

Kroll, Jeri Uneasy Bedfellows: Assessing the Creative Thesis and its Exegesis Vol 3 No 2 October 1999

Ledgar, Jenny A Short Person's Guide to Thesis Writing Vol 5 No 1 April 2001

O'Toole, John Logos and Logic Under Siege: Performance and Research in the Performing, Visual and Creative Arts Vol 2 No 1 April 1998 
Perry, Gaylene The Double Life Vol 4 No 2 October 2000

Perry, Gaylene Writing in the dark: Exorcising the Exegesis Vol 2 No 2 October 1998

Sallis, Eva Research Fiction Vol 3 No 2 October 1999

Stewart, Robyn Practice vs Praxis: Constructing Models for Practitioner-based Research Vol 5 No 2 October 2001

Stewart Robyn (Re)inventing Artists' Research: Constructing living forms of theory Vol 7 No 2 Ocotber 2003

Surma, Anne Defining Professional Writing as an Area of Scholarly Activity Vol 4 No 2 October 2000

Taylor, Andrew Creative Work and the Research Quantum Vol 4 No 2 October 2000

Taylor, Andrew The Ghost and the Machine: Creative Writing and the Academic System Vol 3 No 1 April 1999

Woods, Claire A Program Evolves: relocating writing, relocating literary studies Vol 6 No 2 October 2002

Woods, Claire The Art and Craft of the Honours Thesis: A rhetorical enterprise Vol 4 No 2 October 2000

TEXT Special Issue

No 3 April 2004

http://www.griffith.edu.au/school/art/text/

Editors: Julie Fletcher \& Allan Mann

General Editors: Nigel Krauth \& Tess Brady

Text@griffith.edu.au 